\title{
PERBAIKAN DAN PERKUATAN BANGUNAN SEDERHANA AKIBAT GEMPA
}

\author{
Bambang Hadibroto1, Sahala Ronitua ${ }^{2}$ \\ 1Dosen Pengajar Jurusan Pendidikan Teknik Bangunan, Fakultas Teknik, UNIMED, Medan \\ ${ }^{2}$ Alumni Program Studi D3 Teknik Sipil, Fakultas Teknik, UNIMED, Medan \\ 1Surel : hadibroto@unimed.ac.id \\ Diterima : 21 Mei 2018; Disetujui : 31 Mei 2018
}

\begin{abstract}
ABSTRAK
Bangunan yang sering rusak apabila gempa bumi terjadi adalah bangunan sederhana atau bangunan non-engineering. Bangunan non-engineered adalah bangunan yang umumnya merupakan bangunan penduduk, rumah tinggal, dan lain-lain yang kebanyakan didirikan oleh masyarakat biasa tanpa bantuan ahli struktur. Telah banyak bangunan yang rusak akibat gempa, Sehingga sangat dibutuhkan pengembangan metode perbaikan dan perkuatan struktur bangunan untuk memperbaiki dan memperkuat bangunan yang rusak akibat gempa. Titik-titik lemah bangunan yang merupakan titik-titik kegagalan bangunan akibat beban gempa, antara lain : join fondasi-kolom, join balok-kolom, dinding pasangan dan sistem struktur atap. Dibutuhkan perbaikan pada elemen-elemen tersebut untuk mengembalikan fungsinya seperti semula serta elemen-elemen tersebut sangat membutuhkan perkuatan sebelum terjadi gempa serta pendetailan penulangan yang akurat. Perbaikan dan perkuatan elemen struktur bangunan yang telah dikembangkan antara lain : perbaikan dinding retak dengan metode plesteran yang diperkuat kawat, melapisi elemen struktur bangunan dengan lapisan beton baru, penambahan tulangan dan lapisan beton pada elemen balok, kolom dan pelat, pembuatan jangkar pada setiap 6 lapis bata dan pembuatan kolom praktis pada dinding roboh serta perbaikan dan perkuatan pada rangka atap dan plafon. Material yang digunakan dalam pelaksanaan pekerjaan perbaikan dan perkuatan bangunan sederhana akibat gempa adalah beton, baja tulangan, batu bata, bahan kimia (epoxy) untuk mempercepat proses pekerjaan serta bahan-bahan umum lainnya yang sering dijumpai dalam pelaksanaan pekerjaan kontruksi
\end{abstract}

Kata Kunci : Bangunan Sederhana (Non-Engineering), Perkuatan, Perbaikan

\begin{abstract}
Buildings are often damaged when the earthquake occurred is a simple building or non-building engineering . Non - engineered buildings are buildings that generally are residential buildings, houses, and others are mostly established by ordinary people without the help of expert structures. Final Project is made using the method of literature study, by collecting data from a variety of books, sources and journals related to the repair and retrofitting of buildings is simple due to the earthquak. Has many buildings damaged by the earthquake, so that the much needed development of repair methods and retrofitting structures to improve and strengthen the buildings damaged by the earthquake. Weak points of the building which is the failure points of the building due to earthquake load, among others : the join - column foundation, beam - column joint, and systems partner walls roof structure. Needed improvements to these elements to restore its original function as well as those elements in desperate need before the earthquake retrofitting and reinforcement detailing accurate. Repair and strengthening of structural elements of the building that have been developed include : repair cracked wall plaster reinforced with wire method, coating the structural elements of the building with a new layer of concrete ,reinforcement and the addition of a layer of concrete on the elements of beams, columns and plates, on the manufacture of each 6 -layer anchor brick and manufacture practical columns on the walls collapsed and the repair and reinforcement on the roof frame and the ceiling. Materials used in the execution of repair work and simple retrofitting buildings caused by the earthquake is concrete, reinforcing steel, bricks, chemicals (epoxy) to speed up the work process as well as other common ingredients that are often encountered in the implementation of the construction works.
\end{abstract}

Keywords: building a simple (non - engineering), Rretrofitting, Repair. 


\section{1) Pendahuluan}

Gempa bumi, sebagai kegiatan alami sering diartikan atau dibayangkan sebagai bencana alam. Gempa bumi itu sendiri, tidak menimbulkan bencana secara langsung kepada manusia. Tetapi kerusakan bangunan, runtuhnya gedung, rumah dan bangunan lainnya yang dapat menimbulkan bencana, yaitu korban jiwa dan kerugian harta benda serta problem sosial yang diakibatkan oleh kerugian tersebut.

Sampai saat ini manusia belum dapat berbuat banyak untuk mencegah terjadinya gempa bumi. Walaupun demikian manusia dapat mengurangi akibat buruk yang ditimbulkan oleh gempa bumi dengan merencanakan dan membangun bangunan tahan gempa atau memperkuat bangunan buatannya. Dengan usaha dan upaya manusia (dengan pengetahuan teknologi yang maju) sangat mungkin mencegah/mengurangi bencana yang diakibatkan secara langsung ataupun tidak langsung oleh gempa tersebut.

Sebagian besar korban jiwa dan kerugian material yang terjadi pada setiap gempa bumi disebabkan oleh rusak atau runtuhnya bangunan-bangunan sederhana atau yang disebut juga bangunan non-engineered. Bangunan non-engineered adalah bangunan yang umumnya merupakan bangunan penduduk, rumah tinggal, sekolah, rumah ibadah dan lain-lain yang kebanyakan didirikan oleh masyarakat biasa tanpa bantuan ahli struktur.

Disetiap terjadinya gempa sebagian dari bangunan-bangunan tersebut mengalami kerusakan berat, kerusakan ringan, namun tidak roboh. Kerusakan-kerusakan yang terjadi pada bangunan sederhana biasanya terletak pada join pondasi dengan kolom, join kolom dengan balok, dinding pasangan dan sistem struktur atap. Untuk menangani kerusakan tersebut, perobohan bangunan merupakan alternatif yang sering diambil. Hal ini keliru, tidak semua bangunan yang rusak akibat gempa harus dirobohkan. Perlu dilakukan analisis terlebih dahulu sebelum bangunan itu dirobohkan. Apakah bangunan tersebut hanya perlu diperbaiki pada setiap elemen bangunan yang rusak saja atau memang perlu bangunan dirobohkan seluruhnya.

Permasalahan yang ditinjau berdasarkan latar belakang masalah diatas, dapat diidentifikasikan beberapa masalah antara lain sebagai berikut :
1) Apa saja kerusakan yang ditimbulkan oleh gempa?

2) Bagaimana cara perbaikan dan perkuatan kolom dan balok yang rusak akibat gempa?

3) Bagaimana cara perbaikan dan perkuatan dinding retak dan roboh akibat gempa?

4) Bagaimana sistem struktur atap ?

5) Alat dan bahan apa saja yang digunakan dalam perbaikan dan perkuatan bangunan sederhanayang rusak akibat gempa?

\section{Kajian Pustaka}

\subsection{Gempa Bumi}

Gempa bumi adalah getaran atau guncangan yang terjadi di permukaan bumi akibat pelepasan energi dari dalam secara tiba-tiba yang menciptakan gelombang seismik (http://id.wikipedia.org/wiki/Gempa_bumi).

Gempa bumi biasa disebabkan oleh pergerakan kerak bumi (lempeng bumi). Frekuensi suatu wilayah, mengacu pada jenis dan ukuran gempa bumi yang di alami selama periode waktu. Gempa bumi diukur dengan menggunakan

alat

Seismometer. Moment magnitudo adalah skala yang paling umum di mana gempa Bumi terjadi untuk seluruh dunia. Skala Rickter adalah skala yang di laporkan oleh observatorium seismologi nasional yang di ukur pada skala besarnya lokal 5 magnitude. kedua skala yang sama selama rentang angka mereka valid. gempa 3 magnitude atau lebih sebagian besar hampir tidak terlihat dan besar nya 7 lebih berpotensi menyebabkan kerusakan serius di daerah yang luas, tergantung pada kedalaman gempa.

\subsection{Pengaruh Gempa Bumi Terhadap Struktur} Gempa bumi dapat menimbulkan bahaya dan bencana yang pada umumya terjadi akibat rusak atau runtuhnya gedung-gedung dan bangunan-bangunan buatan manusia lainnya. Sampai saat ini manusia masih belum dapat berbuat banyak untuk mencegah terjadinya gempa bumi. Walaupun demikian manusia dapat mengurangi akibat buruk yang ditimbulkan oleh gempa dengan merencanakan dan membangun bangunan tahan gempa atau memperkuat bangunan buatannya.

Bangunan tahan gempa ada 2 tipe yaitu (1) bangunan tahan gempa konvensional yang mengandalkan kekuatan bahan bangunannya yaitu sifat elastik (kaku) dan sifat 
liat (daktail), sifat kaku dimiliki oleh bahan dari beton dan pasangan batu, sedangkan sifat liat dimiliki oleh logam, kayu dan bambu, (2) bangunan dengan isolator dasar (base isolator). Base isolator merupakan bahan yang terbuat dari karet dan baja lunak yang ditempatkan di antara fondasi (sub structure) dan sloof/kolom (super structure) yang berfungsi mereduks i/mengurangi energi gempa/percepatan tanah dasar ke bangunan sehingga sifat merusak dari gempa dapat diminimalkan.

Dari hasil studi lapangan pada kejadian dan kerusakan bangunan akibat gempa menunjukkan bangunan yang dominan mengalami kerusakan adalah bangunan penduduk (non-engineered structures) mencapai 85\% dari total kerusakan. Daerah Sulawesi Tengah khususnya Kota Palu merupakan salah satu daerah di Indonesia dengan resiko gempa yang tinggi. Dilihat dari segi geoteknik, peraturan perencanaan tahan gempa untuk rumah dan gedung belum sepenuhnya memperhatikan aspek geologii dan seismologi. Bangunan belum didesain berdasarkan kondisi tanah setempat dan catatan gempa terbaru. Mempelajari dan menganalisis kenyataan tersebut, maka sangat dibutuhkan segala usaha yang bertujuan untuk melakukan penelitian, penyuluhan, pelatihan serta peraturan yang bertujuan untuk melakukan upaya pengurangan dampak bencana.

Usaha-usaha tersebut dapat berupa kegiatan aktif seperti penelitian bangunan tahan gempa, perkuatan dan perbaikan bangunan yang belum tahan terhadap gempa berdasarkan peraturan bangunan tahan gempa terbaru. Dapat pula berupa kegiatan pasif seperti pelatihan dan kursus bagi para pekerja konstruksi yang langsung bersentuhan di lapangan, sehingga bangunan yang kan dibangun sudah memenuhi kaidah bangunan tahan gempa, sehingga jika di masa mendatang terjadi gempa, maka kerusakan yang terjadi dapat direduksi seminimal mungkin. Kerugian harta benda dan jiwa dapat diminimalisasi.

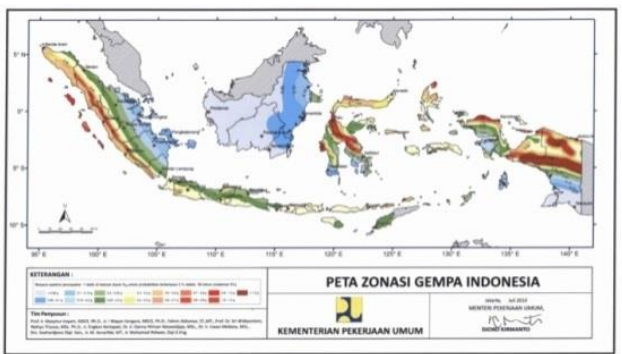

Gambar 1. Peta Zona Gempa Indonesia Tahun 2010 (Sumber : Kementerian Pekerjaan Umum)
Pemerintah melalui Kementerian Pekerjaan Umum telah mengesahkan peta zona gempa Indonesia terbaru pada tahun 2010, seperti pada gambar 1 di atas, dengan kondisi peta terbaru tersebut, Kota Palu berada pada wilayah yang sangat rawan. Terlebih Kota Palu dilintasi oleh Sesar Palu- Koro yang sangat aktif, sekalipun tipe gempanya adalah gempa sesar normal, namun harus tetap diwaspadai. Kekhawatiran tersebut sangat beralasan terutama karena semua bangunan yang telah dibangun belum mengadopsi perencanaan beban gempa terbaru, yang jauh lebih besar dibandingkan beban gempa rencana sebelumnya.

Kerusakan yang ditimbulkan gempa bergantung pada beberapa parameter, yaitu :

1) Karakteristik Goncangan Gempa

Pada lokasi bangunan, gempa bumi akan menyebabkan tanah dibawah bangunan dan di sekitarnya tergoncang dan bergerak secara tak beraturan (random). Percepatan tanah terjadi dalam tiga dimensi membentuk kombinasi frekwensi getaran dari 0,5 Hertz sampal 50 Hertz.

Jika bangunan kaku (fixed) terhadap tanah (dan tidak dapat tergeser) gaya inersia yang menahan percepatan tanah akan bekerja pada tiap-tiap elemen struktur dari bangunan selama gempa terjadi. Besarnya gaya-gaya inersia ini tergantung dari berat bangunannya, semakin ringan berarti semakin kecil gaya inersia yang bekerja dalam elemen struktur tersebut.

Tanggung jawab sebagai orang yang berkecimpung dalam industri konstruksi adalah mendirikan bangunan sedemikian rupa sehingga bangunan tetap mampu berdiri menahan gaya-gaya inersia tersebut. Pertanyaan yang timbul kemudian, "Berapa kekuatan bangunan yang kita perlukan ?".

2) Karakteristik Tanah

Pergerakan gempa untuk mencapai permukaan tanah dipengaruhi oleh kondisi tanah setempat. Lapisan tanah di bawah permukaan yang menopang fondasi bangunan dapat meningkatkan besarnya beban gempa yang dialami oleh struktur bangunan. Hal ini dimungkinkan karena adanya kemungkinan bahwa periode alami dari lapisan tanah di bawah permukaan sama/ hampir sama dengan periode alami dari bangunan diatasnya. Gelombang gempa dengan frekuensi yang tinggi atau periode yang 
kecil akan merambat secara efisien dibatuan dasar yang keras dan tanah keras, yang sebaliknya akan mengurangi atau menghilangkan gelombang gempa yang mempunyai frekuensi rendah. Sebaliknya tanah yang lunak akan menjadi penghantar yang baik untuk gelombang gempa dengan frekuensi yang rendah (periodenya tinggi).

Pada umumnya, periode alami lapisan permukaan tanah berkisar antar 0.5 sampai 1.0 detik. Sedangkan bangunan bertingkat rendah sampai menengah mempunyai periode alami antara 0.1 sampai 1.0 detik. Jelas disini bahwa adalah sangat mungkin untuk terjadi resonansi antara lapisan permukaan tanah dengan bangunanbangunan diatasnya.

3) Karakteristik Bangunan

a. Kekakuan

- Kekakuan suatu bangunan dalam arah vertikal dan horizontal harus terdistribusi secara merata.

- Perbedaan kekakuan suatu bangunan dari satu lantai ke lantai berikutnya meningkatkan kecenderungan rusaknya bagunan jika di goncang gempa.

- Jarak pusat massa dan pusat kekakuan yang berjayhan juga menigkatkan kecenderunga rusaknya bangunan tersebut jika

b. Kekuatan digoncang gempa

- Struktur harus memiliki kekuatan untuk menahan goncangan gempa dan terutama pengaruh rocking. Rocking umumnya terjadi pada bangunan rumah yang kaku.

- Semua komponen bangunan, pondasi, kolom, balok, dinding, rangka atap, harus disambung satu dengan lainnya agar kalau di goncang gempa bangunan bergetar sebagai suatu kesatuan.

c. Daktilitas

Secara umum, daktilitas berarti kemampuan struktur untuk mengalami lendutan yang besar tanpa megalami keruntuhan. Secara teknik, daktilitas adalah perbandingan antara lendutan sebelum runtuh dengan lendutan saat mulai rusak. Jadi daktilitas adalah kemampuan struktur bangunan gedung untuk mempertahankan kekuatan dan kekakuan yang cukup sehinggga struktur tersebut tetap berdiri walaupun sudah berada diambang keruntuhan. (ditjen-ciptakarya-dpu-2006)

Suatu struktur dikatakan tahan gempa bila secara keseluruhan struktur tersebut mempunyai daktilitas yang tinggi. Untuk itu, bahan yang mempunyai daktilitas tinggi dapat digabungkan dengan bahan yang mempunyai daktilitas rendah dengan proporsi dan penempatan yang tepat sehingga secara keseluruhan struktur tersebut memiliki daktilitas tinggi. Daktilitas terutama diperlukan untuk bangunan yang akan mengalami lendutan besar kalau digoncang gempa, umumnya bangunan dengan tingkat banyak.

4) Tingkat Pembebanan Gempa

Pada tahun 1981, studi untuk menentukan besarnya "beban gempa rencana" sudah dilakukan. Studi ini adalah proyek kerja sama antara Pemerintah Indonesia-New Zealand yang menghasilkan. Peraturan Muatan Gempa Indonesia. Konsep peraturan tersebut ada 2 (dua) langkah pendekatan untuk menghitung pembebanan gempa yang dapat digunakan.

Pertama, bahwa perencanaan pembebanan gempa sedemikian rupa sehingga tidak terjadi kerusakan struktur atau kerusakan arsitektural setiap kali terjadi gempa. Kriteria kedua meskipun terjadi gempa yang hebat bangunan tidak boleh runtuh tetapi hanya boleh kerusakan-kerusakan pada bagian struktur yang tidak utama atau kerusakan arsitektur saja. Telah diketahui bahwa adalah tidak ekonomis merencanakan bangunan tahan gempa cara elastis. Jadi untuk gempa yang besar dimana kemungkinan terjadinya kira-kira 15\% dari umur bangunan tersebut, dipakai harga perencanaan yang rendah dan perencanaan khusus serta ukuran detaildetail diambil sedemikian sehingga menjamin beberapa bagian tertentu dari struktur akan Ieleh (berubah bentuk dalam keadaan plastis) untuk menyerap sebagian enersi gempa (yang berlaku untuk keadaan kenyal). Besarnya harga beban rencana yang terjadi berhubungan dengan beberapa faktor yang selengkapnya terdapat pada reference, yang disimpulkan sebagai berikut:

a. Faktor Lapangan (site) 


\section{Perbaikan Dan Perkuatan Bangunan Sederhana Akibat Gempa}

Parameter ini dimodifikasikan untuk perhitungan pada kondisi tanah Iunak dimana goncangan tanah akibat gempa akan diperbesar (mengalami pembesaran).

Untuk Jakarta, pada zone 4 dan diatas tanah lunak koefisien beban rencana lateral adalah 0,05 untuk struktur yang kaku seperti perumahan bertingkat rendah.

b. Faktor Bangunan

Beban yang terjadi pada suatu bangunan juga tergantung pada keadaan (features) dari bangunan rersebut, yakni fleksibilitasnya, beratnya dan behan bangunan untuk konstruksinya.

Biasanya suatu bangunan yang fleksibel akan menerima beban gempa yang Iebih kecil dibandingkan bangunan yang lebih kaku. Bangunan yang lebih ringan akan menerimna beban gempa yang Iebih keciI dari pada bangun yang berat dan bangunan yang kenyal akan menyerap beban gempa yang lebih kecil dari pada bangunan yang getas yang mana dalam keadaan pengaruh gempa akan tetap elastis atau runtuh secara mendadak.

Bangunan dari kayu digolongkan sebagai bangunan yang kenyal. Untuk struktur kayu harus direncanakan dengan menggunakan Peraturan Muatan Indonesia yang baru. Beban rencana adalah $33 \%$ - 50\% dari gaya yang menyebabkan struktur belum mulai leleh atau masih dalam keadaan elastis.

Ini tidaklah sama besarnya untuk bahan bangunan yang lain, misalnya baja yang mempunyai kekenyalan yang lebih besar dari kayu. Meskipun demikian kekenyalan dapat diciptakan dalam struktur kayu dengan menggunakan alat penyambung yang kenyal pada tiap-tiap hubungan elemen stuktur kayu tersebut. Pada umumnya, sambungan dengan paku memberikan kekenyalan yang cukup.

c. Tingkat Pembebanan Gempa untuk Bangunan Kayu

Dengan memperhatikan faktor lapangan dan faktor bangunan, struktur kayu harus tetap mampu berdiri untuk menahan beban-beban sebagai berikut : (Jakarta, tanah lunak)

- $\quad$ Rangka kayu kenyal : 0,05 *) x 1,7 = 0,085

- $\quad$ Dinding geser kayu : 0,05 *) $\times 2,5=$ 0,125

- Konstruksi rangka kayu yang diperkuat dengan batang pengaku diagonal: $\left.0,05{ }^{*}\right) \times 3=0,15$

Keterangan :

*) Faktor ini mempunyai harga maksimum 0,13 pada zone 1(satu) dan 0 pada zone 6 (enam)

Hal ini berarti, misalnya suatu dinding geser yang terbuat dari plywood atau particle board, harus dapat menerima gaya horisontal sebesar $0,125 \times$ berat total dari bagian struktur yang membebani dinding tersebut.

Meskipun suatu bangunan
direncenakan $\begin{array}{r}\text { dengan } \\ \text { pembebanan yang benar, mungkin }\end{array}$
bangunan. tersebut mengalami
kerusakan akibat gempa jika sebagian
dari prinsip-prinsip utamanya tidak
dipenuhi.

\subsection{Dasar Perencanaan Tahan Gempa}

a. Mutu Konstruksi

Dua hal yang harus diperhatikan dalam membangun rumah tahan gempa adalah mutu bahan yang digunakan dan mutu pengerjaannya. Kedua hal tersebut sangat mempengaruhi mutu rumah yang akan dibangun.

Jika mutu bahan yang digunakan baik, belum tentu menghasilkan rumah yang baik jika pengerjaannya tidak baik. Begitu juga sebaliknya, jika mutu pengerjaan baik tetapi bahan yang digunakan tidak memadai dan tidak sesuai dengan sfesifikasi yang telah ditentukan, mutu rumah yang dihasilkan rendah. Jadi kedua hal tersebut harus terpenuhi untuk dapat menghasilkan rumah yang bermutu.

b. Denah Yang Sederhana Dan Simetris

Penyelidikan kerusakan akibat gempa menunjukkan pentingnya denah bangunan yang sederhana dan elemen-elemen struktur penahan gaya horisontal yang simetris. Struktur seperti ini dapat menahan gaya gempa Iebih baik karena kurangnya efek torsi dan kekekuatannya yang lebih merata.

c. Bahan Bangunan Harus Seringan Mungkin

Seringkali, oleh karena ketersedianya bahan bangunan tertentu. Arsitek dan Sarjana sipil harus menggunakan bahan 
bangunan yang berat, tapi jika mungkin sebaiknya dipakai bahan bangunan yang ringan. Hal ini dikarenakan besarnya beban inersia gempa adalah sebanding dengan berat bahan bangunan.

Sebagai contoh penutup atap genteng diatas kuda-kuda kayu menghasilkan beban gempa horisontal sebesar $3 \times$ beban gempa yang dihasilkan oleh penutup atap seng diatas kuda-kuda kayu. Sama halnya dengan pasangan dinding bata menghasilkan beban gempa sebesar $15 \mathrm{x}$ beban gempa yang dihasilkan oleh dinding kayu.

d. Perlunya Sistem Konstruksi Penahan Beban Yang Memadai

Supaya suatu bangunan dapat menahan gempa, gaya inersia gempa harus dapat disalurkan dari tiap-tiap elemen struktur kepada struktur utama gaya horisontal yang kemudian memindahkan gaya-gaya ini ke pondasi dan ke tanah.

Sangat penting bahwa struktur utama penahan gaya horizontal itu bersifat kenyal. Karena, jika kekuatan elastis dilampaui, keruntuhan getas yang tiba-tiba tidak akan terjadi, tetapi pada beberapa tempat tertentu terjadi Ieleh terlebih dulu.

Suatu contoh misalnya deformasi paku pada batang kayu terjadi sebelum keruntuhan akibat momen lentur pada batangnya. Cara dimana gaya-gaya tersebut dialirkan biasanya disebut jalur Iintasan gaya. Tiap-tiap bangunan harus mempunyai jalur lintasan gaya yang cukup untuk dapat menahan gaya gempa horisosontal.Untuk memberikan gambaran yang jelas, disini diberikan suatu contoh rumah sederhana dengan tiga hal utama yang akan dibahas yaitu struktur atap, struktur dinding dan pondasi.

- Struktur Atap

Jika tidak terdapat batang pengaku (bracing) pada struktur atap yang menahan beban gempa dalam arah $\mathrm{X}$ maka keruntuhan akan terjadi. Jika lebar bangunan lebih besar dari lebar bangunan di mungkin diperlukan 2 atau 3 batang pengaku pada tiap-tiap ujungnya. Dengan catatan bahwa pengaku ini harus merupakan sistim menerus sehingga semua gaya dapat dialirkan melalui batang-batang pengaku tersebut. Gaya-gaya tersebut kemudian dialirkan ke ring balok pada ketinggian langit-langit. Jika panjang dinding pada arah lebar (arah pendek) lebih hesar dari 4 meter maka diperlukan batang pengaku horisontal pada sudut untuk memindahkan beban dari batang pengaku pada bidang tegak dinding daIam arah $X$ dimana elemnen-elemen struktur yang menahan beban gempa utama. Sekali lagi ring balok juga harus menerus sepanjang dinding dalam arah $X$ dan arah $\mathrm{Y}$ sebagai pengganti penggunaan batang pengaku diagonal pada sudut, ada 2 (dua) alternatif yang dapat dipilih oleh perencana;

1. Ukuran ring balok dapat diperbesar dalam arah horisontal, misalnya $15 \mathrm{~cm}$ menjadi $30 \mathrm{~cm}$ atau sesuai dengan yang dibutuhkan dalam perhitungan. Ring bolok ini dipasang diatas dinding dalam arah X.

2. Dipakai langit-langit sebagai diafragma, misalnya plywood.

Untuk beban gempa arah $\mathrm{Y}$, sistim struktur dibuat untuk mencegah ragam keruntuhan. Untuk mengalirkan gaya dari atap kepada dinding dalam arah Y, salah satu alternatif diatas dapat dipilih yaitu penggunaan batang pengaku horisontal ring balok atau memakai langit-langit sebagai diafragma.

\section{- Struktur Dinding}

Gaya-gaya aksiaI dalam ring balok harus ditahan oleh dinding. Pada dinding bata gaya-gaya tersebut ditahan oleh gaya tekan diagonal yang diuraikan menjadi gaya tekan dan gaya tarik. Gaya aksiaI yang bekerja pada ring balok juga dapat menimbulkan gerakan berputar pada dinding. Putaran ini ditahan oleh berat sendiri dinding, berat atap yang bekerja diatasnya dan ikatan sloof ke pondasi. Jika momen guling lebih besar dari momen penahannya maka panjang dinding harus diperbesar. Kemungkinan lain untuk memperkaku dinding adalah sistim diafragma dengan menggunakan plywood, particle board atau sejenisnya, atau pengaku diagonal kayu untuk dinding bilik. Penggunaan dinding diafragma lebih dianjurkan karena sering terjadi kesulitan untuk memperoleh sambungan ujung yang lebih pada sistim pengaku diagonal. Beban gempa 
yang bekerja pada arah $\mathrm{Y}$ ditahan dengan cara yang sama dengan arah $X$. Sebagal sistem struktur utama yang mana dinding harus mampu menahan beban gempa yang searah dengan bidang dinding, dinding juga harus mampu menahan gempa dalam arah yang tegak lurus bidang dinding.

Dengan alasan ini maka dinding bata (tanpa tulangan) harus diperkuat dengan kolom praktis dengan jarak yang cukup dekat. Sebagai pengganti kolom praktis ini dapat dipakai tiang kayu.

Kekuatan dinding tembokan dipengaruhi oleh :
a. Kekuatan bata
b. Kekuatan adukan siar
c. Ketebalan adukan siar
d. Tingkat awal penyerapan air oleh bata
e. Variasi ukuran bata
f. Mutu pengerjaan
g. Perawatan (Curing)

Struktur pondasi

Struktur pondasi berperanan penting untuk memindahkan beban gempa dari dinding ke tanah. Pertama, pondasi harus dapat menahan gaya tarik vertikal dan gaya tekan dari dinding. Ini berarti sloof menerima gaya geser dan momen lentur sebagai jalur Iintasan gaya terakhir sebelum gayagaya tersebut mencapai tanah.

Sloof memindahkan gaya-gaya datar tersebut ke pada tanah yang ditahan oleh daya dukung tanah dan tekanan tanah lateral. Rumah yang terbuat dari kayu dengan lantai kayu dan pondasi kayu memerlukan batang pengaku untuk mencegah keruntuhan.

\subsection{Kerusakan Tiikal Bangunan Sederhana (Non-Engineering) Akibat Gempa}

Sistem struktur bangunan sederhana (nonengineering) biasanya memakai sisitem struktur

1) Kontruksi dinding pemikul

- Memikul beban vertikal dan beban lateral (unconfined masonry).

2) Kontruksi dinding dengan rangka

- Dinding dengan bingkai rangka sederhana untuk menahan beban vertikal dan beban lateral (unconfined masonry).
- Rangka balok dan kolom kaku untuk menahan beban vertikal dan beban lateral serta diberi dinding pengisi.

Kerusakan gempa adalah suatu simulasi sesungguhnya, tingkah laku sesungguhnya akibat beban sesungguhnya. Kerusakan atau robohya bangunan disebabkan beban tegak lurus bidang dinding. Namun demikian, penyebab utama kerusakan adalah akibat beban tegak lurus bidang dinding.

Kerusakan tipikal bangunan sederhana di Indonesia berdasarkan hasil pengamatan selama kurang lebih 35 tahun adalah sebagai berikut :

1) Genteng melorot

2) Dinding berpisah pada pertemuan dua dinding

3) Kehancuran pada pojok-pojok dinding

4) Dinding retak di sudut-sudut bukaan

5) Dinding retak diagonal

6) Dinding roboh

7) Kegagalan sambungan balok dan kolom

8) Bangunan roboh

\subsection{Sebab Kerusakan Bangunan Sederhana (Non-Engineered) Akibat Gempa}

Pada umumnya, kerusakan atau robohnya dinding disebabkan beban tegak lurus bidang dinding dan beban sejajar bidang dinding. Namun demikian, penyebab utama kerusakan adalah akibat beban tegak lurus bidang dinding. di samping itu, kerusakan juga disebabkan oleh mutu bahan yang rendah, mutu pengerjaan yang rendah, dan kurangnya pemeliharaan.

1) Bangunan tembokan tanpa perkuatan Sebab-sebab kerusakan antara lain:

a. Bangunannya relatif berat

b. Bangunannya getas (tidak daktail)

c. Tidak kuat menahan tarikan yang terjadi akibat gaya gempa yang bekerja di arah tegak lurus bidang dinding.

2) Bangunan tembokan dengan perkuatan Sebab-sebab kerusakan anatara lain:

a. Tidak ada jangkar untuk mengikat dinding dengan unsur-unsur perkuatan

b. Tidak ada unsur-unsur perkuatan bidang dinding yang luasnya $\geq 6$ $\mathrm{m}^{2}$.

c. Detail penulangan yang tidak benar pada pertemuan unsurunsurperkuatan 
d. Mutu beton kolom praktis, balok keliling, dan pondasi sangat rendah

e. Diameter dan total luas penampang tulanga yag dipasang terlalu besar.

\subsection{Katagori Kerusakan}

1) Kerusakan Ringan Non-Struktur

Suatu bangunan dikategorikan mengalami kerusakan nonstruktur apabila terjadi hal-hal sebagai berikut :

a. retak halus (lebar celah lebih kecil dari $0,075 \mathrm{~cm}$ ) pada plesteran

b. serpihan plesteran berjatuhan

c. mencakup luas yang terbatas

Tindakan yang perlu dilakukan adalah perbaikan (repair) secara arsitektur tanpa mengosongkan bangunan.

2) Kerusakan Ringan Struktur Suatu bangunan dikategorikan mengalami kerusakan struktur tingkat ringan apabila terjadi hal-hal sebagai berikut.

a. retak kecil (lebar celah antara 0,075 hingga $0,6 \mathrm{~cm}$ ) pada dinding.

b. plester berjatuhan.

c. mencakup luas yang besar.

d. kerusakan bagian-bagian nonstruktur seperti cerobong, lisplang, dsb.

e. kemampuan struktur untuk memikul beban tidak banyak berkurang.

f. Laik fungsi/huni

Tindakan yang perlu dilakukan adalah perbaikan (repair) yang bersifat arsitektur agar daya tahan bangunan tetap terpelihara. Perbaikan dengan kerusakan ringan pada struktur dapat dilakukan tanpa mengosongkan bangunan.

3) Kerusakan Struktur Tingkat Sedang

Suatu bangunan dikategorikan mengalami kerusakan struktur tingkat sedang apabila terjadi hal-hal sebagai berikut :

a. retak besar (lebar celah lebih besar dari $0,6 \mathrm{~cm}$ ) pada dinding;

b. retak menyebar luas di banyak tempat, seperti pada dinding pemikul beban, kolom; cerobong miring; dan runtuh;

c. kemampuan struktur untuk memikul beban sudah berkurang sebagian;

d. laik fungsi/huni.
Tindakan yang perlu dilakukan adalah :

a. restorasi bagian struktur dan perkuatan (strenghtening) untuk menahan beban gempa;

b. perbaikan (repair) secara arsitektur;

c. bangunan dikosongkan dan dapat dihuni kembali setelah proses restorasi selesai.

4) Kerusakan Struktur Tingkat Berat

Suatu bangunan dikategorikan mengalami kerusakan struktur tingkat berat apabila terjadi hal-hal sebagai berikut:

a. dinding pemikul beban terbelah dan runtuh;

b. bangunan terpisah akibat kegagalan unsur-unsur pengikat;

c. kira-kira 50\% elemen utama mengalami kerusakan;

d. tidak laik fungsi/huni.

Tindakan yang perlu dilakukan adalah merubuhkan bangunan. Atau dilakukan restorasi dan perkuatan secara menyeluruh sebelum bangunan dihuni kembali. Dalam kondisi kerusakan seperti ini, bangunan menjadi sangat berbahaya sehingga harus dikosongkan.

5) Kerusakan Total

Suatu bangunan dikategorikan sebagai rusak total / roboh apabila terjadi hal-hal sebagai berikut:

a. Bangunan roboh seluruhnya ( $>65 \%$ )

b. Sebagian besar komponen utama struktur rusak

c. Tidak laik fungsi/ huni

Tindakan yang perlu dilakukan adalah merubuhkan bangunan, membersihkan lokasi, dan mendirikan bangunan baru.

\subsection{Bahan Dan Alat Yang Digunakan Untuk Perbaikan dan Perkuatan Bangunan Sederhana}

1) Bahan

a. Beton

Beton adalah campuran antara semen portland atau semen yang lain dengan agregat halus, agregat kasar, air, dan bahan tambahan yang membentuk massa dengan komposisi tertentu untuk dapat menahan gaya tekan. (SK SNI 03-2847-2002-6). Jack C. McCormac (2003:1) menyatakan beton adalah suatu campuran yeng terdiri dari pasir, kerikil, batu pecah, atau agregatagregat lain lain yang dicampur menjadi satu dengan suatu pasta yang terbuat dari 
semen dan air membentuk massa miripbatuan. Terkadang, satu atau lebih bahan aditif ditambahkan untuk menghasilkan suatu beton dengan karakteristik tertentu, seperti kemudahan pengerjaan (workability), durabilitas dan waktu pengerasan.

Beton memiliki kuat tekan yang tinggi dan kuat tarik yang rendah. Beton Bertulang adalah suatu kombinasi antar beton dan baja dimana tulangan baja berfungsi menyediakan kuat tarik yang tidak dimiliki oleh beton.

Perbandingan percampuran bahan pembentuk beton dilakukan berdasarkan volume. Perbandingan berdasarkan volume harus dilakukan setepat mungkin agar kekuatan beton yang dikehendaki dapat tercapai. Cara sederhana menakar banyaknya air, semen, pasir, dan kerikil dapat dilakukan dengan menggunakan ember dengan ukuran yang sama. Dengan perbandingan 1 semen : 2 pasir : 3 kerikil : $1 / 2$ air, seperti pada Gambar 2 dibawah ini.

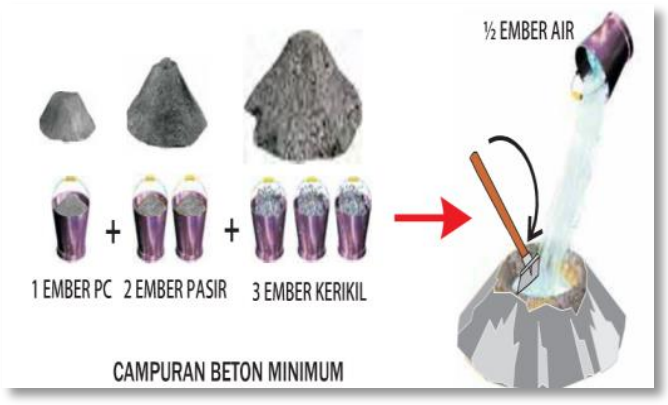

Gambar 2. Perbandingan Pencampuran Bahan Pembentuk Beton (Boen, T., 2005)

2) Bahan Pembentuk Beton

Adapun bahan-bahan pembentuk beton adalah :

a. Semen

Semen adalah komponen beton yang berfungsi sebagai bahan pengikat hidrolis, yang bila dicampur dengan air akan mengakibatkan proses pengerasan. Semen yang biasa dipergunakan adalah semen Portland. Semen yang sering diperdagangkan terdiri atas berbagai jenis atau tipe.

b. Agregat

Agregat adalah unsur beton berupa butir-butir mineral yang diperoleh dari hasil disintegrasi alami batuan atau dari proses pemecahan batuan ditinjau dari ukurannya, agregat terdiri dari dua macam, yaitu :
1. Agregat halus Agregat halus adalah bahan batuan berupa pasir yang diperoleh dari hasil disentegrasi batuan.

2. Agregat kasar

Agregat kasar adalah bahan batuan berupa batu pecah atau kerikil (koral).

c. Air

Air yang digunakan untuk campuran beton paling baik adalah air bersih yang memenuhi syarat air minum.

Bahan lainnya :

- Baja tulangan

- Kawat pengikat dan kawat anyam

- Kayu dan multiplek

- Paku

- Bahan kimia (epoxy)

2) Alat

Adapun alat yang digunakan antara lain:

- Meteran

- Sendok Spesi

- Roskam

- Siku

- Gergaji Tangan

- Palu

- Sekop

- Dongkrak

2.8 Perbaikan dan Perkuatan Bangunan Sederhana Akbat Gempa

1) Perbaikan

Tujuan utama dari perbaikan adalah untuk mengembalikan bentuk arsitektur bangunan agar semua perlengkapan atau peralatan dapat berfungsi kembali. Perbaikan tidak ada kaitannya dengan struktur.

Tindakan-tindakan yang termasuk kategori ini meliputi :

a. Menambal retak-retak pada tembok, plesteran, dll.

b. Memperbaiki pintu, jendela, mengganti kaca, dll.

c. Memperbaiki kabel-kabel listrik.

d. Memperbaiki pipa air, pipa gas, saluran pembuangan.

e. Membangun kembali dinding-dinding pemisah dan pagar.

f. Memplester kembali dinding-dinding

2) Restorasi

Tujuan dari restorasi adalah untuk melakukan perbaikan pada komponenkomponen struktur penahan beban dan mengembalikan kekuatan semula. 
Tindakan-tindakan yang termasuk kategori ini meliputi :

a. Menginjeksikan air semen atau bahan-bahan epoxy ke dalam retakretak kecil yang terjadi pada dinding pemikul beban, balok maupun kolom

b. Penambahan jaringan tulangan pada dinding pemikul, balok, maupun kolom yang mengalami retak besar kemudian diplester kembali.

c. Membongkar bagian-bagian dinding yang terbelah dan menggantikannya dengan dinding baru dengan spesi yang lebih kuat dan dijangkar pada portal.

d. Membongkar bagian kolom atau balok yang rusak, memperbaiki tulangannya, lalu dicor kembali.

3) Perkuatan

Tujuan dari perkuatan adalah membuat bangunan menjadi lebih kuat dari kekuatan semula

Tindakan-tindakan yang termasuk kategori ini meliputi :

a. Menghilangkan sumber-sumber kelemahan atau yang dapat menyebabkan tejadinya konsentrasi tegangan di bagian-bagian tertentu, antara lain :

- Penyebaran kolom yang tidak simetris

- Penyebaran letak dinding yang tidak simetris.

- Beda kekakuan yang besar antara lantai yang satu dengan yang lainnya

- Bukaan-bukaan yang berlebihan.

b. Menjadikan bangunan sebagai satu kesatuan dengan jalan mengikat semua komponen-komponen penahan beban satu dengan yang lainnya.

c. Menghindarkan terjadinya kehancuran getas dengan cara memperbaiki, menambah, dan memasang tulangn sesuai dengan detail-detail untuk mencapai daktilitas yang cukup.

d. Menambah daya tahan terhadap beban lateral, dengan jalan menambah dinding, menambah kolom, dll

\section{Simpulan}

Berdasarkan hasil pembahasan penulis pada perbaikan dan perkuatan rumah sederhana akibat gempa, penulis dapat mengambil kesimpulan sebagai berikut :

1) Perbaikan dan perkuatan elemen struktur bangunan yang rusak oleh gempa dilakukan dengan cara antara lain : perbaikan dinding retak dengan metode plesteran yang diperkuat kawat, melapisi elemen struktur bangunan dengan lapisan beton baru, penambahan tulangan dan lapisan beton pada elemen balok, kolom dan pelat, pembuatan jangkar pada setiap 6 lapis bata dan pembuatan kolom praktis pada dinding roboh serta perbaikan dan perkuatan pada rangka atap dan plafon.

2) Material yang digunakan pada perbaikan dan perkuatan bangunan sederhana akibat gempa adalah material yang mudah ditemukan atau material yang umum dipakai pada pelaksanaan pekerjaan bangunan. Seperti beton, batu bata, baja tulangan, serta bahan kimia (epoxy) untuk mempercepat pekerjaan

\section{Daftar Pustaka}

Boen, T., 2012 Perbaikan dan Perkuatan Bangunan Tembokan Sederhana.

Boen, T., 2010, Cara Memperbaiki Bangunan Sederhana yang Rusak Akibat Gempa Bumi,

Boen, T., 2005, Dasar-Dasar Membangun Bangunan Tembokan Tahan Gempa.

RSNI3 03-1726-201x, Tata Cara Perencanaan Ketahanan Gempa Untuk Struktur Bangunan Gedung dan Non Gedung

Ditjen-Cipta-Karya-Dpu, 2006, Pedoman Teknis Rumah Bangunan Tahan Gempa

Sulendra, I Ketut., 2011, Evaluasi dan Tindakan Pengurangan Kerusakan Bangunan Berdasarkan Peta Zonasi Gempa Tahun 20102.7 Bahan Dan Alat Yang Digunakan Untuk Perbaikan dan Perkuatan Bangunan Sederhana 